\title{
FACTORS THAT DETERMINE THE ADOPTION OF SCIENTIFIC INDICATORS IN COMMUNITY-BASED MONITORING OF MANGROVE ECOSYSTEMS IN TANZANIA
}

Daniel SABAI *

* University of Dar es Salaam, Faculty of Humanities and Social Sciences, College of Education, Geography and Economics Department, P. O. Box 2329, Dar es Salaam, dosabai@yahoo.co.uk

DOI: 10.2478/trser-2019-0003

KEYWORDS: mangroves, monitoring, indicators, learning, knowledge.

\begin{abstract}
This article reveals factors that need to be considered by facilitating institutions and organisations prior to adoption of scientific indicators in community-based monitoring of mangrove ecosystems; as a necessary route towards achieving effective participation and meaningful experiential learning processes. It employs an Experiential Learning Intervention Workshop (ELIW) as a key methodological tool and a useful space for analysing conditions that are necessary for adoption of scientific frameworks in the Tanzanian coastal area. ELIW also offers an opportunity for local people to share knowledge and decide the kind of input required for monitoring mangroves and fisheries.

RÉSUMÉ: Facteurs déterminant l'adoption des indicateurs scientifiques dans la surveillance communautaire des écosystèmes des mangroves de Tanzanie.

Cet article montre les facteurs à prendre en compte par les institutions et les organisations faciliter avant l'adoption des indicateurs scientifiques dans l'adoption communautaire des écosystèmes des mangroves, un parcours nécessaire pour l'obtention d'une participation efficace et des processus d'apprentissage d'expériences utiles. Il utilise un Atelier d'Intervention pour l'Apprentissage d'Experiences (ELIW) en tant qu'instrument méthodologique clé et d'espace utile pour l'analyse des conditions nécessaires à l'adoption des cadres scientifiques pour la zone côtière tanzanienne. ELIW offre aussi l'opportunités aux habitant locaux de partager leurs connaissances et à décider quelles sont les ajouts nécessaire pour la surveillance des mangroves et la pêche.
\end{abstract}

REZUMAT: Factori determinanți în adoptarea indicatorilor științifici în monitorizarea comunitară a ecosistemelor de mangrove din Tanzania.

Lucrarea de față indică factorii ce trebuie să fie luați în considerare de instituțiile și organizațiile facilitatoare înainte de adoptarea indicatorilor științifici pentru monitorizarea comunitară a ecosistemelor de mangrove, parcurs necesar pentru o participare eficientă și pentru obținerea unor procese de învățare din experiență care să aibă sens. Lucrarea a folosit rezultatele Atelierului de Intervenție pentru Învățare prin Experiență Practică (ELIW) folosit ca instrument metodologic cheie și spațiu util de analiză a condițiilor necesare pentru adoptarea cadrelor de lucru știinţifice în zona de coastă a Tanzaniei. ELIW oferă şi posibilitatea localnicilor de a-și pune în comun cunoștințele și a decide ce fel de informații sunt necesare pentru monitorizarea mangrovelor și zonelor de pescuit. 


\section{INTRODUCTION}

Mangroves are salt-tolerant plant species that grow in intertidal coastlines in subtropics and tropics, serving as habitats for biological diversity and nurseries for fish resources (Tomlison, 1994; IUCN, 2006; Aluri, 2013). They play significant ecological roles, including carbon sequestration, pollutants filtration, hydrological cycle, coastal protection against soil erosion, flood control, and expansion of coastal land by trapping sediments and binding them together as part of the coastal landmass (Mazda et al., 2002; Aziz and Hashim, 2011; Lee et al., 2014). Mangroves also serve as a source of income for coastal people and a space for social functions and practices (UNEP, 2014).

In the last 25 years, there were observed intentional actions of coastal countries, principally low income states, to engage local communities in participatory monitoring of coastal and marine resources such as mangroves, fisheries, coral reefs, seagrass and coastal land on social, economic, and ecological grounds. (NICEMS, 2003; Wagner, 2005)

Community-based mangrove ecosystem monitoring has been successfully conducted in other countries, including India and Sri Lanka (Datta et al., 2010; IUCN, 2011) and in the Philippines (Daupan, 2016). Top, post-2004 Indian Ocean tsunami mangrove rehabilitation efforts in Thailand clearly demonstrated multi-generation community involvement together with strong "social capital" building on existing mangrove dependency like fishing (Paphavasit et al., 2008) and will typically underachieve or fail if real local participation is lacking (Soegiarto, 2008). The International Union for Conservation of Nature (2008) reports very successful multi-sector, post 2004 tsunami community participation (women, students, children, scientists and international volunteers) in a Maldives coastal rehabilitation project featuring mangroves.

Efforts have also been made to provide an overview of key processes and directives on the right approaches and procedures that may help communities to improve mangrove management initiatives and encourage active participation (Schmitt and Duke, 2015). A call has also been made to encourage various countries to decentralize mangrove management initiatives as a necessary element of sustainability (Datta et al., 2012).

Some of the key drivers that justify community involvement in the management of the coastal resources include such ecological systems contain a wide range of productive habitats necessary for subsistence and sustenance of poor communities who rely on them for survival (UNCED, 1992; NICEMS, 2003). There is no doubt that such initiatives are carried out in countries that are parties to the Rio de Janeiro-Earth Summit of 1992, which among other reasons, work to comply with the obligations of chapter 17 of the Agenda 21; which require member states to prioritize integrated coastal management initiatives in their own countries (UNCED, 1992).

Community-based mangrove monitoring initiatives were introduced in several countries in the mid and late 1990s, including those that are located near the Indian Ocean such as Madagascar, Mauritius, Seychelles, Somali Republic, Union of Comoros, Kenya and the United Republic of Tanzania (RECOMAP, 2009). In Tanzania, such initiatives were started in five coastal regions, namely Dar es Salaam, Coast, Lindi, Mtwara, and Tanga. Specifically, the following programs were operational in the specified coastal regions. These include; Tanga Coastal Zone Conservation and Development Programme (TCZCDP), Rufiji Environment Management Project (REMP), National Mangrove Management Project (NMMP), Rural Integrated Project Support (RIPS), Mafia Island Marine Park (the first Marine Park in Tanzania) established under the Marine Parks and Reserve ACT.29 of 1994, Kinondoni Integrated Coastal Area Management Programme (KICAMP) and Saadani Mkwaja Game Reserve (TCMP, 1998; TCZCDP, 2005). 
The emphasis on participatory monitoring of coastal and marine resources in Tanzania did not aim at reducing incidences of unsustainable practices through mechanistic approaches. The focus was to expose coastal communities to processes and practices that would enable them to learn and share knowledge as they continue to take part in participatory programs (NEECS, 2005-2009). This could help them to see things differently and adopt positive attitudes towards the sustainability of mangroves and other coastal and marine resources.

Lotz-Sisitka (2012) argues that community-based natural resource management creates a space for learning and encourages knowledge sharing, experimentation, reflective practice, problem solving, effective monitoring and informed planning; leading to behavioural change and trust. Leys and Vanclay (2010) view such forms of learning as an approach that can strengthen communities' capacity to collectively manage ecosystems sustainably.

While learning through direct involvement in practice is necessary (Kuper et al., 2009), much relies on the methods and the indicators employed by development experts and scientists in participatory natural resource management initiatives, such as monitoring of mangroves resources and fisheries. In East Africa, (particularly Tanzania where Integrated Coastal Management Programmes were initiated in early, mid to late 1990s under internal and external funding) specific monitoring plans were developed by scientific institutions to guide community-based monitoring practices (KICAMP, 2005). The said monitoring plans contained scientific indicators and attributes adopted from the Survey Manual for Tropical Marine Resources (English et al., 1994, 1997), which are similar to those put forward by the Science and Technical Working Group (STWG) of Tanzania Coastal Management Partnership (KICAMP, 2005).

After few years of implementing community-based monitoring plans, the local participants (coastal communities) still struggled to understand and apply the scientific framework of indicators (KICAMP, 2005). This fact was affirmed, when one of the studies carried out by Julius (2005) along the eastern Coast of Tanzania indicated that there was no effective monitoring of coastal and marine resources. This implied that learning through participatory monitoring practices did not yield positive results as previously envisaged. Campbell (2000) affirms that problems emerge when facilitating firms and organisations prioritize natural scientific norms and approaches in community-based initiatives.

Proceedings from the scientific forum on Integrated Coastal Management issues in Tanzania indicate that scientific knowledge was being presented in a manner that was too complicated that tended to limit understanding and access to information for management purposes (TCMP, 1998).

This journal article does not suggest that the adoption and application of scientific indicators and methodologies in the local context constrain the learning process. It rather raises a concern whether or not conditions that necessitate development or adoption of scientific knowledge are properly addressed by experts and scientists prior to involving or engaging target communities in the participatory monitoring of coastal and marine resources, particularly the mangroves and fisheries that use them as key habitats. The article seeks to communicate a special message to different actors who are involved in coastal-based monitoring practices; that effective learning in community-based initiatives may not occur by simply adopting models, plans, and frameworks from other contexts, but by addressing key conditions that are necessary for stimulating and mobilising the learning process. These are presented here as key findings and described further using theoretical insights. 
This research produce information on the elements that require to be considered by coastal practitioners before adopting scientific indicators from other geographical areas and put them into use in their own coastal specidic contexts. Prduced knowledge stems from experienced coastal communities in Mkinga District, who reveal the difficulties they have experienced as an effect of adopting the attributes and indicators from different contexts. The study complements the captured knowledge with existing literature sources to help the facilitators of participatory coastal monitoring practices in the Eastern Coast of Tanzania and other actors from similar contexts to use the generated knowledge as a guide for communitybased monitoring of coastal resources (particularly mangroves and mangrove-based fisheries). The study also suggests a new methodological tool called "The Experiential Learning Intervention Workshop (ELIW)" for facilitating participatory analysis of the adopted framework of scientific indicators and attributes. This tool was developed in 2013 by the author of this journal article in a $\mathrm{PhD}$ research process which was carried out in the Eastern Coast of Tanzania (Sabai, 2014) and can serve as a useful method for analysis and learning. Moreover, it offers a space for coastal communities to generate and use existing traditional ecological knowledge in improving the adopted frameworks. Procedures for its application are covered under the material and methods section.

\section{MATERIAL AND METHODS}

This research was carried out in the mangrove ecosystem area restoration context in the eastern coast of Tanzania. It intended to analyse challenges that emerge as a result of adopting scientific indicators in the study area (Mkinga District), which in one way or another, can enable or constrain the learning process where participatory monitoring of coastal and marine resources is carried out. The study also sought to examine the possibility of employing existing local knowledge as an input for complementing adopted scientific framework of indicators and a response to the challenges raised by research participants (coastal communities). Embarking on this kind of study was also a response to the advice given by some scientists that local input is required when developing participatory monitoring indicators in order to accurately measure what is locally important (Fraser et al., 2005).

Research strategy This was a case study strategy which according to Yin (2003), allows the investigator to retain holistic and meaningful characteristics of real-life events that occur in the mangrove ecosystem. Opting for this strategy also implied choosing to have a deeper understanding of phenomena under study (depth) than how wide they are (breadth). Case study research yields either descriptive or explanatory knowledge (Babbie, 2001, 2007). This strategy, therefore, allowed selected fishers, mangrove restorers and local elders who have experienced real-life mangrove and fishery events to share their knowledge under the facilitation of the researcher, in the presence of invited marine scientists.

Sampling The sampling process was guided by Vershuren and Doorewaard (1999) who recommend the use of a strategic sample to allow in-depth analysis of the phenomenon under study. Selection of research participants was based on their previous involvement in mangrove and fishery practices in the study area. Using this criterion, the study selected fishers who had participated in fishing activities for at least 15 years, mangrove restorers with at least 10 years record and local elders who had witnessed trends, threats, changes and conditions of fisheries and mangrove resources for at least 20 years. Using previous contacts, the researcher formed a team of five experienced mangrove restorers and fishers (three females and two males) to assist in the process of selecting potential workshop participants. The team suggested a total of 26 participants whom they believed to have met the specified sampling criteria. 


\section{Data generation and analysis}

The inquiry process was carried out through the Experiential Learning Intervention Workshop (ELIW) as a key methodological tool and a useful space for analysing conditions that are necessary for adoption of proposed monitoring approaches or scientific frameworks in a specified case study. The ELIW was completed in four sessions, across two workshop days. This allowed mangrove restorers, mangrove-based fishers, local elders and marine scientists to mirror the scientific framework of indicators and specifically analyse challenges that are associated with the adoption and application of the same.

\section{Procedures adopted in the ELIW as a methodological tool}

The Experiential Learning Intervention Workshop (ELIW) enabled workshopparticipants to verify data from individual responses, analyse the same, and create a learning space throughout the workshop sessions. The method may be applied in a community of researchers, academicians, teachers, students, fishers, mangrove restorers, and in any other context where generation of data is possible. It is a useful methodological tool that may potentially attract and enhance learning through guided interactions (Sabai, 2014).

The main tool for guiding the ELIW was the framework of scientific indicators which was developed in Australia (English et al., 1994, 1997) by a team of marine scientists (Tab. 1). As stated in the introduction section, the attributes and indicators of this framework were adopted in Tanzania and applied in various coastal sites (inclusive in the study area). The workshop participants were therefore facilitated to analyse the usefulness of this particular framework after several years of its adoption.

The intervention workshop was divided into four main sessions. The first session focused on analysing the level of familiarity and comprehension of attributes that constitute the framework of scientific indicators for monitoring mangrove species and mangrove-based fisheries respectively (Tab. 1).

Table 1: The scientific framework of indicators developed outside East Africa and adopted by Tanzania in the 1990s for its coastal management initiative (KICAMP, 2005; English et al., 1994; Hill et al., 2005).

\begin{tabular}{|c|c|}
\hline $\begin{array}{l}\text { Scientific attributes/indicators } \\
\text { for monitoring mangroves }\end{array}$ & $\begin{array}{l}\text { Scientific attributes/indicators } \\
\text { for monitoring mangrove-based } \\
\text { fisheries }\end{array}$ \\
\hline $\begin{array}{l}\text { Community structure and biomass } \\
\text { Primary productivity } \\
\text { Leaf litter production } \\
\text { Soil characteristics } \\
\text { Area coverage } \\
\text { Species composition and diversity } \\
\text { Dynamics (change) }\end{array}$ & $\begin{array}{l}\text { Population size } \\
\text { Population structure } \\
\text { Breeding success } \\
\text { Weight and length of fish by species } \\
\text { Type of gear used to catch the fish } \\
\text { Distance to fishing ground } \\
\text { Type of vessel used and size } \\
\text { Means of vessel propulsion } \\
\text { Number of crew } \\
\text { Incidental catches of endangered species }\end{array}$ \\
\hline
\end{tabular}


The second session focused on identifying and associating scientific monitoring methods and techniques to the attributes or indicators identified during the first session. The third session aimed at examining the capacity of the participants to apply the framework. This session focused on capturing challenges that users of the framework experienced in the process of applying the scientific framework of indicators in the field and recording the same in special sheets.

The first two sessions were introduced to pave the way for the participants to recall various monitoring moments they had gone through and recognize different challenges that either enabled or constrained them from acquiring knowledge as they took part in the practice. The fourth and last session aimed at analysing the relevance of the indicators to the local context, identify emerging errors, correct observed errors, add local input to improve the framework and produce a user friendly framework (which is contextually relevant and cultural friendly), test the new framework, and provide feedback of the testing exercise. (Figs. 2-4)

\section{RESULTS}

\section{Level of familiarity and comprehension}

This section presents the results on the level of familiarity and comprehension experienced among the workshop participants (Fig. 1). The results suggest that $65 \%$ of the participants did not understand the components of the framework due to a couple of reasons; including language difficulties experienced, too many components in the framework of indicators, lack of formal knowledge, illiteracy, and unknown reasons. 25\% of the participants partially understood the components and only $10 \%$ of the participants understood the components (their little formal knowledge coupled with opportunities for attending different training workshops helped them to understand).

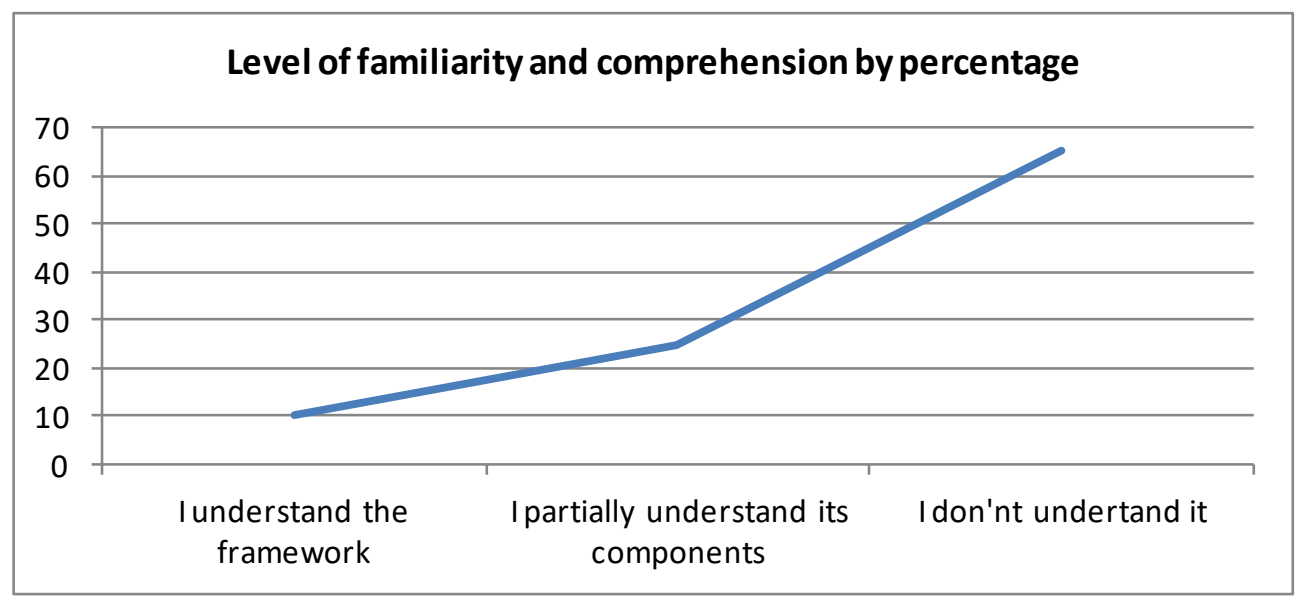

Figure 1: Level familiarity and comprehension of the framework of indicators for mangroves and mangrove-based fisheries. 


\section{Ability to apply the scientific framework of indicators}

$50 \%$ of the ELIW-participants reported that they were unable to apply the indicators while $40 \%$ were able to apply them partially. Reasons for the failure included the level of reification and contextual challenges.

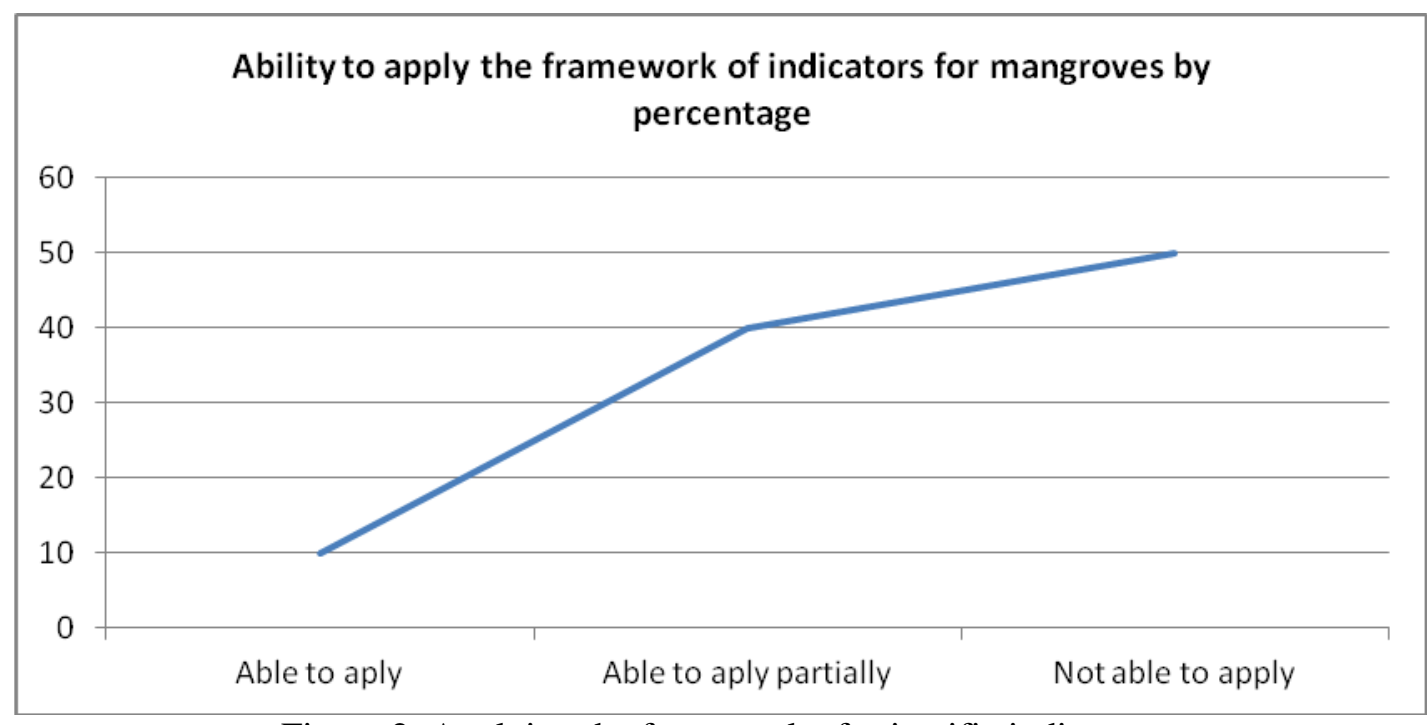

Figure 2: Applying the framework of scientific indicators for monitoring mangroves.

\footnotetext{
Ability to apply the scientific framework of indicators for monitoring mangrovebased fisheries

45\% of the Experiential Learning Intervention Workshop (ELIW) participants reported that they were able to apply the indicators while $40 \%$ were unable to use certain attributes in the list. This suggests that the framework for monitoring mangrove-based fisheries was somehow clearer to users than the one adopted for monitoring mangroves. It also suggests that when developing or adopting frameworks, it is necessary to ensure that used components are tuned to reflect the context within which it will be applied.

In spite of promising results in the application of mangrove-based fisheries indicators and attributes, the percentage of those who reported they are able is not significant. Captured reasons are more or less similar to those raised by mangrove restorers. The results, therefore, raise the need for facilitating institutions, organisations and other key players to undertake needs assessment in potential project or programme areas, to uncover necessary conditions that need to be met before the implementation of any development programmes in the coastal area.
} 


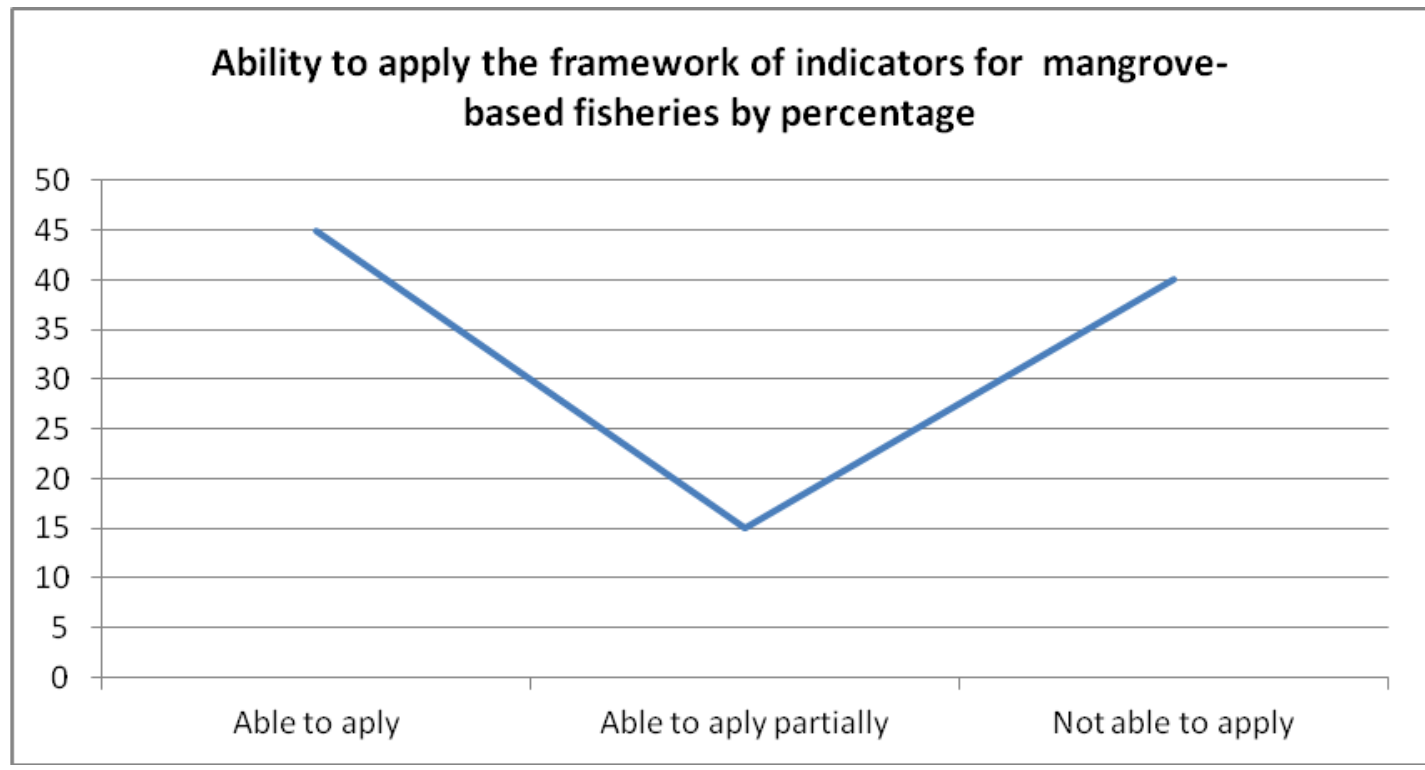

Figure 3: Applying the framework of scientific indicators for fisheries.

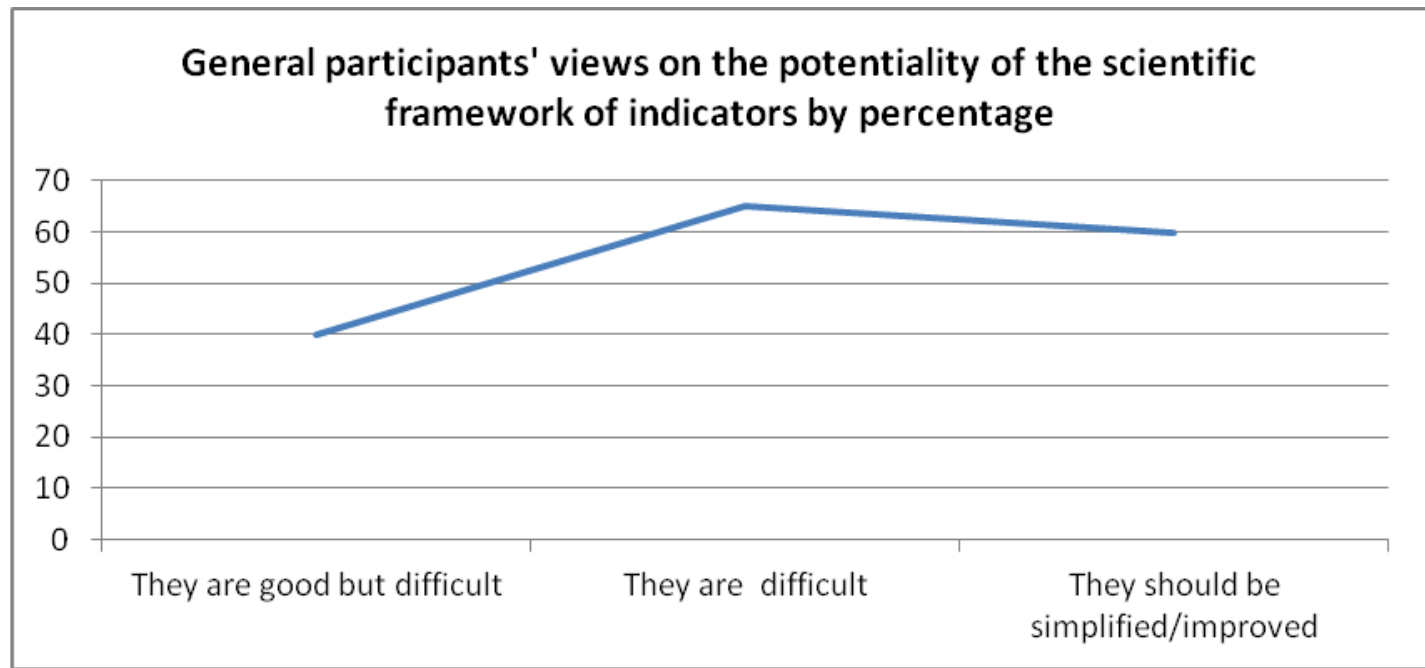

Figure 4: General perceptions of the ELIW participants.

The adoption of the scientific framework of indicators poses a number of challenges that need to be addressed prior to adoption of new frameworks (Fig. 4).

\section{DISCUSSION}

Challenges raised from the Experiential Learning Intervention Workshop suggest a list of conditions that determine or necessitate the adaption of scientific knowledge in a mangrove monitoring scenario. These included the level of education that the participating group has, level of participation opted for, contextual realities on the ground, consideration of the potential input that target communities have, and the level of structures opted for. All these determinants are discussed here after. 


\section{Level of education}

One of the conditions that require attention is, for example, the capacity of the target communities to adapt and apply scientific methodologies. This appears to be necessary since literacy levels, especially in the developing countries, vary across regions. In one of the studies carried out in the eastern coast of Tanzania by a team of marine scientists, a random sample of 145 individuals was taken for purposes of analysing their socio-economic status, including the level of education. The results indicated that the level of education among target communities was very low. About one-third of the population (31\%) had no formal education at all, $26 \%$ had reached only up to standard IV, $3 \%$ had completed standard VII, and only $2 \%$ had received post-primary education. The study also revealed that women had generally lower literacy and educational levels than men (Wagner et al., 2001).

In another coastal monitoring context, an assessment was carried out in the same area by one of the capacity building programmes through a two-day participatory workshop to establish the capacity of coastal communities and local government staff to understand and apply the adapted monitoring plan. It was observed that the latter were more conversant with the indicators and methodologies used in the plan than the former (KICAMP, 2005). The difference was ascribed to the varying levels of formal education between the two. The level of practical experience amongst the two groups could not be taken as a confounding factor since both participants were exposed to the plan at the same time and had no prior knowledge of it. This suggests that there is a close link between literacy and numeracy skills and the capacity to adapt and apply scientific indicators and methodologies. In other words, understanding is a prerequisite for taking part effectively in the practice. Reed et al. (2010) argued that for learning to occur in a community of practice (as it is the case with the participatory coastal monitoring initiatives), involved individuals must demonstrate a change in "understanding", and be able to share their knowledge with other participants to the level that will attract more involvement and wider participation of other community members in the same practice.

\section{Level of participation}

The second condition that comes out so strongly in the community-based monitoring is deciding the level of participation that is required for community involvement. This involves taking part in choosing educational tools that are suitable in the learners' context. It depicts a doctor-patient scenario where involvement and willingness of the patient in the prescription process is necessary. Some facilitators tend to assume that target communities (learners) may only be involved at particular levels of the initiatives, whereas others do not involve them at all (Songorwa, 1999). Campbell and Vainio-Mattila (2003) insist that target communities should influence the conception, design, and implementation of the introduced initiatives. Influencing the conception and the design implies taking part in deciding the structure, approach, and materials that suit their need and situations that address the actual reality in a coastal and marine setting.

There are two options that are normally preferred by facilitators when laying down strategies for participatory learning initiatives at the local level. The first option is to use adapted tools such as models, framework of indicators, plans, and any other interventional methods or techniques (KICAMP, 2005). This approach is common and mostly favoured as discussed earlier in the introduction part. The second option sets opportunities for target communities to create their own monitoring tools depending on conditions that prevail in their context and thereafter apply them. The latter option seems to carry on board the real meaning 
of participation or participatory approaches and is probably least favoured. Choosing either of the two needs to be decided and agreed by involved individuals and social groups in every community-based scenario. Comprehension of the said tools emerge to be an important factor, since as discussed earlier, learning can hardly occur without understanding (Reed et al., 2010). Campbell and Vainio-Mattila (2003) argue that communities are not passive bystanders in the on-going or introduced initiatives but have to be actively engaged in the negotiations that determine what those initiatives will look like.

\section{Contextual realities on ground}

It is observed that long-term change in the initiatives that local communities are involved in may only be realised or experienced if an emphasis will be laid on situated knowledge. Campbell and Vainio-Mattila (2003) defines this as "a process whereby access to the information, and control over knowledge use shifts from experts and scientists to the people whose lives are being affected". Situating knowledge in a particular learning context requires consideration of various elements. Indicator development for the monitoring of mangroves as a practice that stimulates learning should thus be rooted in contextual realities. Arguing in favour of prioritizing contextual information, Glahn et al. (2007) states that actors depend on indicators in order to organise, orientate and navigate through complex environment by utilising contextual information. Contextual information has been proven as important to support the learning processes. It stimulates the learners' engagement in and commitment to collaborating processes; it helps to raise awareness of and stimulates reflection about acquired competences; it supports thoughtful behaviour in navigation and learning paths. Glahn et al. (2007) not only insists on developing indicators that are relevant to the context within which they will be applied, but also brings into view the fact that the processes which lead to development of indicators are closely linked to learning. In other words, it implies that involving local actors, such as coastal communities, in such processes or practices create opportunities for them to learn from each other and, therefore, understand better both the context and the indicators they have developed. This may also suggest that imposing or causing actors to adapt indicators from other contexts deprives them of opportunities for learning and compels them to apply tools that are not their own creation.

According to ITAD (1997), the measures that the indicators suggest must be contextually appropriate, clear and acceptable to target communities to avoid misrepresentation of information, over-reporting or underreporting of events. The indicators should also be cost-effective, relevant to the context, and easy to apply or use. Scheltinga et al. (2004) also emphasized the need to avoid complexity by also avoiding technical abstractions and embarking on simple processes that can be easily be measured, analysed, and interpreted by involved communities. Rydin et al. (2003) noted a wave of change in indicator development, from a technical process which involves experts (at global level) to a participatory process which focuses on understanding the local context within which the indicators are being developed as a process that focuses on the relationship between lay people and experts. They argue that if indicator development is no longer a technical issue, then it should not be left to experts, but rather to people who are directly affected by the situation. Indicator development should thus be centred on the learner's situation or context and not on static approaches, which according to Glahn et al. (2007) follow a fixed set of rules in the process of collecting, aggregating, and indicating information to learners. 
As indicated earlier, comprehension is a key element in the learning process without which learning of whatever kind can hardly be attained or attracts a wider level (Reed et al., 2010). Reed et al. (2006) identified two key criteria for indicators: ability of users (learners) to apply them and their relevance at local level, as discussed earlier. For users of the indicators to meet the first criterion (ability to apply them), they must first comprehend them. The level of comprehension amongst them will depend on the level reification and abstraction that underpin their involvement in the initiatives they are undertaking. If, for example, the development of the said indicators pursued a formal natural science route, common people who have never had access to participate in formal learning can hardly understand them. However, if the abstractions favour the local context and the learners or users are part of the process that led to development of such indicators, they are likely not only to understand the indicators but interact and share new knowledge with other local actors.

It is also recommended to learn from target communities whether or not there are cultural aspects that need to be addressed or considered in the monitoring plans prior to adapting any frameworks or tools. This is an important aspect, since culture in most societies is closely linked or related to moral values. (Medin and Atran, 2008)

When it is regarded as a moral duty, it may create a binding situation which compels a defined community to abide by what is believed to be morally acceptable. In this manner, culture may either serve as an enabler or constraining factor. For example, if mangrove forest sites are regarded or designated by a particular local community as being sacred, visiting such areas may be restricted to specified individuals and opportunities for other member of the community including the facilitators to undertake conservation or management activities may be limited. Development of monitoring indicators should thus consider what may be acceptable in a particular culture and what may not. This can be reached by consulting target social groups and encouraging processes that will allow them to take part at all levels of the monitoring plan, as well as through the implementation process.

\section{The level of structures opted for}

The kind of structures preferred by facilitators may well affect the process of developing community-based monitoring programmes and ultimately enable or constrain the learning process. Reed et al. (2006) presented two paradigms that determine the development of indicators in the local context as being the top-down and bottom-up. The process that leads to development of indicators under the top-down paradigm tend to exclude contextual aspects and do not encourage consultation of local communities as does the bottom-up approach. Indicators that result from the latter provide a more contextualised understanding of local issues and guarantee sustainability, ownership and accountability of participating learners. Fraser et al. (2005) remind development experts (facilitators) to ensure that the process of choosing indicators should consider their relevance to local situations.

\section{Consideration of local input}

There is evidence that local communities that are involved in participatory monitoring of coastal and marine resources are hardly asked to share experiences and situated knowledge for purposes of informing the conception and implementation of planned initiatives. Campbell and Vainio-Mattila (2003) present two cases where 
marine scientists continued to rely heavily on western scientific criteria in determining conservation practices. Fraser et al. (2005) insist on the fact that local input is required when developing community-based monitoring indicators in order to accurately measure what is locally important. Commenting on the need to consider local knowledge in the monitoring process, Berkes (2012) states that as people with a detailed understanding of the environment and accumulation of observations over generations (e.g. indigenous groups) have a special place in community-based monitoring. He further argues that it is becoming clear that many indigenous groups have developed their own traditional monitoring systems based on their own ways of knowing.

Most traditional monitoring methods used by indigenous people are rapid, low-cost, and easily comprehensible by harvesters themselves as they hunt, fish, and gather the forest products. Berkes (2008) observes that insights of indigenous wisdom offer great potential for broadening epistemological access, given the difficulties and limitations of accessing and using scientific knowledge in addressing complex ecological challenges. Such difficulties emerge when scientific institutions favour the language of description and methodologies that are too difficult for non-specialists at the community level to follow, leading to limited epistemological access between scientific institutions and local communities (Reed et al., 2006). Reid et al. (2006) advised that ways have to be explored in which scientific (western) and traditional knowledge can be used together, and conditions necessary for such integration need to be better understood.

\section{CONCLUSIONS}

The article raises the need for actors at institutional and organizational levels to examine contextual realities in the coastal settings prior to adoption of scientific frameworks or approaches. Knowledge of the level of formal education that the target group has, realization of the minimum level of participation that is required, consideration of the structures that govern coastal monitoring practices at the local level, and incorporation of existing traditional ecological knowledge (as local input) may potentially attract smooth adoption process and generate a sense of ownership, belonging, active participation and active experiential learning processes. 


\section{ACKNOWLEDGEMENTS}

To mangrove restorers and fishers in Mkinga District, Tanga, Tanzania, and professors Sisitka H. and O’Donoghue R. from the Environmental Learning Research Centre, Rhodes University. 


\section{REFERENCES}

1. Aluri R., 2013 - Reproductive ecology of mangrove flora: conservation and management, Transylvanian Review of Systematical and Ecological Research, 15.2, The Wetlands Diversity, 133-184.

2. Aziz T. N. A. and Hashim N. R., 2011 - Heavy metal concentrations in an important mangrove palm (Nypa fruticans), in Rembau-Linggi Mangrove Forest (Peninsular Malaysia), Transylvanian Review of Systematical and Ecological Research, 12, The Wetlands Diversity, 111-116.

3. Babbie E., 2001 - The practice of social research, 9th edition, Belmont, Wadsworth Thomson Learning, 116.

4. Babbie E., 2007 - The practice of social research, 11th edition, Belmont, Wadsworth Thomson Learning, 116.

5. $\quad$ Berkes F., 2008 - Sacred ecology, 2nd edition, New York, Routledge, 336.

6. $\quad$ Berkes F., 2012 - Sacred ecology, 3rd edition, New York, Routledge, 392.

7. Campbell L. M., 2000 - Human need in rural developing areas: perceptions of wildlife conservation experts, The Canadian Geographer, 44, 2, 167-181.

8. Campbell L. M. and Vanio-Matilla A., 2003 - Participatory development community-based conservation: opportunities missed for lessons learned, Human ecology, 31, 3, 417-437.

9. Datta D., Guha P. and Chattopadhyay R. N., 2010 - Application of criteria and indicators in community based sustainable mangrove management in the Sunderbans, India, Ocean and Coastal Management, 53, 468-477.

10. Datta D., Chattopadhyay R. N. and Guha P., 2012 - Community based mangrove management: a review on status and sustainability, Journal of Environmental Management, 107, 84-95.

11. Daupan S. M. M. V., 2016 - Community participation in mangrove forest management in the Philippines: management strategies, influences to participation, and socio-economic and environmental impacts. MSc thesis, University of Michigan, 56.

12. English S., Wilkison C. and Baker V. (eds), 1994 - Survey manual for tropical marine resources, ASEAN, Australian marine science project: living coastal resources, Townville, Australian Institute of Marine Science, 368.

13. English S., Wilkinson C. and Baker V. (eds), 1997 - Survey manual for tropical marine resources (2nd edition), AIMS, Townville: AIMS, 390.

14. Fraser E. D. G., Dougill A. J., Mabee W. E., Reed M. and McAlpine P., 2005 - Bottom up and top down: analysis of participatory processes for sustainability indicator identification as pathway to community empowerment and sustainable environmental management, Journal of Environmental Management, 78, 114-127.

15. Glahn C., Specht M. and Koper R., 2007 - Creating new learning experiences on global scale, Berlin, Springer, 56-70.

16. Hill D., Fasham M., Tucker G., Shewry M. and Shaw P. (eds), 2005 - Handbook of Biodiversity Methods: Survey, Evaluation and Monitoring, New York, Cambridge University Press, 106-236.

17. International Union for Conservation of Nature (IUCN), 2006 - Conservation benefits of mangroves, Sri Lanka, 5.

18. International Union for Conservation of Nature (IUCN), 2008 - Socioeconomic and ecological monitoring toolkit: Huraa Mangrove Nature Reserve, Environmental Research Centre, Energy and Water, IUCN Ecosystems, a Livelihoods Group, Asia, 68.

19. International Union for Conservation of Nature (IUCN), 2011 - An appraisal of mangrove management in micro-tidal estuaries and lagoons in Sri Lanka, 116.

20. ITAD, 1997 - IUCN Monitoring and Evaluation Initiative, London, ITAD, 16.

21. Julius A., 2005 - Monitoring Programme for resource condition, environmental and biological parameters for Mnazi-Bay Ruvuma Estuary Marine Park (MBREMP) Tanzania, Research Report submitted for the requirement of United Nations University Fisheries Training Programme, 56. 
22. Kinondoni Integrated Coastal Area Management Programme-KICAMP, 2005 - Phase OneFinal Report, Dar es Salaam, 30.

23. Kuper M., Dionnet M., Hammani A., Bekkar Y., Garin P. and Bluemling B., 2009 Supporting the shift from state water to community water: lessons from a social learning approach to design joint irrigation projects in Morroco, Ecology and Society, 14, 19.

24. Lee S. Y., Primavera J. H., Dahdouh-Guebas F., McKee K., Bosire J. O., Cannicci S., Diele K., Fromard F., Koedam N., Marchand C., Mendelssohn I., Mukherjee N. and Record S., 2014 Ecological role and services of tropical mangrove ecosystems: a reassessment, Global Ecology and Biogeography, 23, 726-743.

25. Leys A. and Vanclay J., 2010 - Stakeholder engagement in social learning to resolve controversies over-land use change to plantation forestry, Regional Environmental Change, 11, 175-190.

26. Lotz-Sisitka H. B. (ed.), 2012 - Reviews on social learning literature: A Monograph for Social learning researchers in natural resources management and environmental education, Grahamstown/Howick: Environmental Learning Research Centre, RhodesUniversity/EEASA/SADC REEP, 93.

27. Mazda Y., Magi M., Nanao H., Kogo M., Miyagi T., Kanazawa N. and Kobashi D., 2002 Coastal erosion due to long-term human impact on mangrove forests, Wetlands Ecology and Management, 10, 1, https://doi.org/10.1023/A:1014343017416.

28. Medin D. and Atran S., 2008 - The native mind and the cultural construction of nature, Massachusetts: Massachusetts Institute of Technology, 333.

29. National Integrated Coastal Environmental Management Strategy (NICEMS), 2003 - Dar es Salaam: TCMP, 43.

30. National Environmental Education and Communication Strategy (NEECS), 2005-2009 - Dar es Salaam: Rihal's General Supplies, 45.

31. Paphavasit N., Piumsomboon A., Sivaipram I., Siriboon S. and Aksornkoae S., 2008 Conceptual model on capacity building of fishing communities in post-tsunami mangrove rehabilitation, in Chan H. T. and Ong J. E. (eds), Proceedings of the Meeting and Workshop on Guidelines for the Rehabilitation of Mangroves and Other Coastal Forests Damaged by Tsunamis and Other Natural Hazards in the Asia Pacific Region, Bangkok, Thailand, 66.

32. RECOMAP, 2009 - Regional Programme for the Sustainable Management of the Coastal Zones of the Indian Ocean Countries, Guidelines for Grant Applications, Indian Ocean Commission, 19.

33. Reed M. S., Fraser E. D. G. and Dougil A. J., 2006 - An adaptative learning process for developing and applying sustainability indicators with local people, Ecological Economics, 59, 406-418, www.elsevier.com/locate/ecolecon (accessed in 29/06/2011).

34. Reed M. S., Evely C. A., Cundill G., Fazey I., Glass J., Laing A., Newig J., Parrish B., Prell C., Raymond C. and Stringer L. C., 2010 - What is Social Learning? Ecology and Society, 15, 4.

35. Reid W. V., Berkes F., Wilbanks T. J. and Capistrano D. (eds), 2006 - Bridging scales and knowledge systems, concepts and applications in ecosystem management, Washington, Island Press, 351.

36. Rydin Y., Homan N. and Wolff E., 2003 - Local sustainability indicators, The International Journal of Justice and Sustainability, 8, 581-589.

37. Sabai D., 2014 - Mobilising processes of abstraction, experiential learning and representation of traditional ecological knowledge, in Participatory monitoring of mangroves and fisheries on the Eastern coast of Tanzania, Doctoral thesis, Rhodes University, Grahamstown, 335.

38. Scheltinga D. M., Counihan R., Moss A., Cox M. and Bennet J., 2004 - User's guide to estuarine, coastal and marine indicators for regional natural resource management, Cooperative Research Centre for Coastal Zone, Estuary and Waterway Management, 4-183. 
39. Schmitt K. and Duke N. C., 2015 - Mangrove management, assessment and monitoring, Berlin Heidelberg: Springer-Verlag, 1-29.

40. Soegiarto A., 2008 - Problems and challenges on the rehabilitation of mangroves ecosystem in Indonesia after the 2004 Indian Ocean tsunami, Proceeding of the meeting and workshop on Guidline for rehabilitation of of Mangroves and other Coastal Forest damaged by tsunami and other natural hazards in the Asia Pacific regions, Okinawa meeting 15-16 June 2007, Workshop Bangkok 23 August 2008.

41. Songorwa A. N., 1999 - Community-based wildlife management (CWM) in Tanzania. Are the communities interested? World Development, 27, 12, 2061-2079.

42. Tanzania Coastal Management Partnership (TCMP), 1998 - An approach for linking science to integrated coastal management, Proceedings of the Scientific meeting on marine and coastal ecosystem risk assessment, Zanzibar, TCMP and IMS, 29.

43. TCZCDP, 2005 - Tanga Coastal Zone Conservation and Development Programme, Annual Progress Report, 1st April 2004 - 31st March 2005, 28.

44. Tomlinson P. B., 1994 - The botany of mangroves, Cambridge University Press, New York, 419.

45. UNCED, 1992 - United Nations Conference on Environment and Development.

46. UNEP, 2014 - The importance of mangroves to people: a call to action, van Bochove J., Sullivan E. and Nakamura T. (eds), United Nations Environment Programme World Conservation Monitoring Centre, Cambridge, 128

47. Vershuren P. and Doorewaard H., 1999 - Designing a research project, Utrecht, LEMMA, 215. (in the Netherlands)

48. Wagner G. M., 2005 - Participatory monitoring of changes in coastal and marine biodiversity, Indian Journal of Marine Sciences, 34, 1, 136-146.

49. Wagner G. M., Mgaya Y. D., Akwilapo F. D., Ngowo R. G., Sekadende B. C., Allen A., Zollet E. A. and Mackentley N., 2001 - Dar es salaam: University of Dar es Salaam, 321.

50. Yin R. K., 2003 - Case study research design and methods, 3rd edition, London, Sage, 181. 